Matej Gogola (Bratislava)

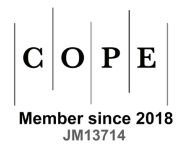

\title{
Prolegomena to the Christian Images Not Made by Human Hands
}

$T_{\text {in }}$ mages not made by human hands (acheiropoietai) played a significant role in Byzantine history as far as the emergence of local spiritual culture was concerned. However, a person not versed in Byzantine iconology and iconography, or in the ecclesiastical history of the Eastern rite as such, might find the phenomenon

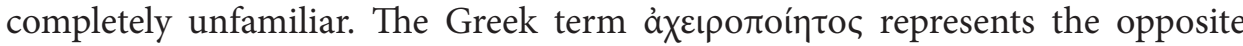

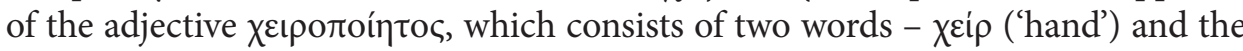

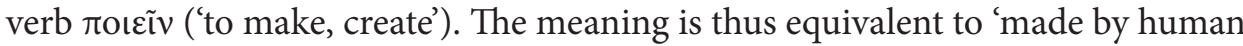
hands' ${ }^{1}$. However, the prefix morpheme á- reverses the semantics, so that áxहlротоі́ $\tau$ то can be literally translated as 'not made by human hands' / 'not created by a human'. Since this interpretation overturned the meaning of the term completely, icons (images) lost their label of objects of idolatry ${ }^{2}$. Images which were not created by a human acquired the status of images created by God, consequently becoming particularly important and revered artefacts ${ }^{3}$.

The well-known German historian and art theorist Hans Belting defined the

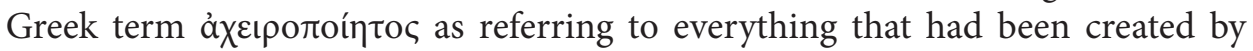
God - including the human being, created in the image of God ${ }^{4}$. The concept of 'not made by human hands' is found already in the New Testament. Specifically, Paul explains in his Second Epistle to the Corinthians that at the moment of our

\footnotetext{
${ }^{1}$ Cf. Mc 14, 58; Act 7, 48; Act 17, 24; Eph 2, 11; Heb 9, 11; Heb 9, 24.

${ }^{2}$ E. von Dовsснüтz, Christusbilder. Untersuchungen zur christlichen Legende, Leipzig 1899 [= TUGAL, 18], p. 357; E. KitzINGER, The Cult of Images in the Age before Iconoclasm, DOP 8, 1954, p. 143.

${ }^{3}$ L. Brubaker, Conclusion: Image, Audience and Place: Interaction and Reproduction, [in:] The Sacred Image. East and West, ed. R. Ousterhout, L. Brubaker, Urbana 1995 [= IBS, 4], p. 214; cf. E. Kitzinger, The Cult..., p. 112-115; R. Cormack, Miraculous Icons in Byzantium and Their Powers, ArtC 76, 1988, p. 60; J. Trilling, The Image Not Made by Hands and the Byzantine Way of Seeing, [in:] The Holy Face and the Paradox of Representation. Papers from a Colloquium Held at the Bibliotheca Hertziana, Rome and the Villa Spelman, Florence, 1996, ed. H.L. Kessler, G. Wolf, Bologna 1998, p. 109-127.

${ }^{4}$ H. Belting, Bild und Kult. Eine Geschichte des Bildes vor dem Zeitalter der Kunst, München 1990; cf. E. von Doвschütz, Christusbilder..., p. 37. And God created man in His image; in the image

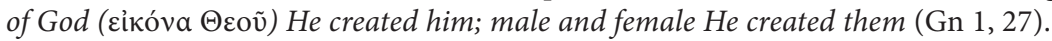


passing to the world beyond, a house not made with hands, eternal in the heavens - a Divine dwelling - awaits us (2Cor 5, 1). In the Gospel of Mark, Christ states that instead of the old temple, he is going to create a new temple not made with hands $(\mathrm{Mc} 14,58)$. In this temple, there would be people circumcised by means of a circumcision not performed by human hands (Col 2, 11).

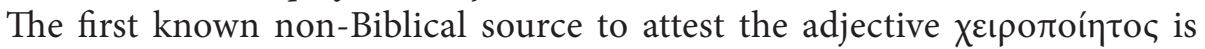
probably even older than the New Testament reference. Historians have dated the text in question - a papyrus letter from a certain Nearchos to Heliodoros ${ }^{5}$ - to the $1^{\text {st }}$ or $2^{\text {nd }}$ century AD. Having ventured up the Nile as far as to the town of Aswan, in the area of the first cataract, the author continued further towards the river's source. Subsequently, he left the Nile and travelled westwards to the Oasis of Siwa in the Libyan Desert, where the oracle of Amon was allegedly located. One can assume that Nearchos encountered numerous sights during his journeys; in the letter, he describes his impressions to his friend. He uses the

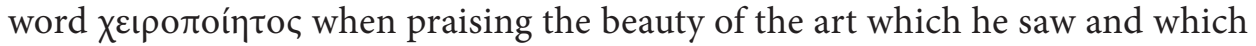
had been created by human hands 6 .

Unfortunately, there is no example such as Nearchos's impressions of his trav-

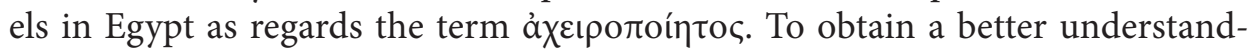

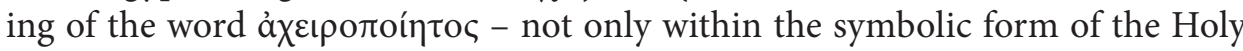
Scripture, but also as far as the source material is concerned - several 'predecessors' of images not made by human hands shall be introduced. Acheiropoietai can be found in sources from the second half of the $6^{\text {th }}$ century onwards and have much in common with their pre-Christian 'relatives': their veneration was based, among other things, on the experience of worshipping images containing pagan motifs in the pre-Christian period.

\footnotetext{
${ }^{5}$ Cf. the different dating by L. Mitteis, U. Wilcken, Grundzüge und Chrestomathie der Papyruskunde, Hildesheim 1963, no. 117, p. 147-148 and Greek Papyri in the British Museum. Catalogue with Texts, vol. III, ed. F.G. Kenyon, H.I. BelL, Milano 1973, p. 205-206.

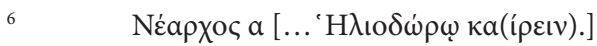

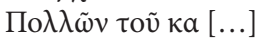

Kà̀ $\mu \varepsilon \dot{\chi} \chi \rho ı ~ \tau o \tilde{~} \pi \lambda \varepsilon \tilde{v} v \varepsilon .[\ldots]$

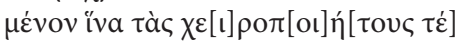

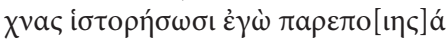

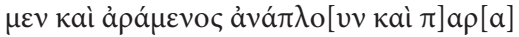

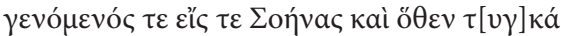

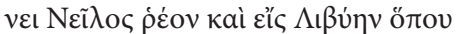

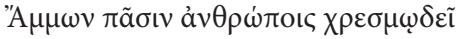

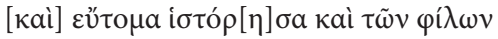

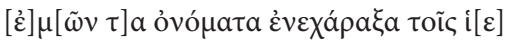

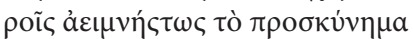

The following two lines are erased

'H $\mathrm{\lambda} \iota$ เо $\omega \dot{\rho} \omega$.

See L. Mitteis, U. Wilcken, Grundzüge..., no. 117, p. 148.
} 


\section{Images in the pre-Christian period}

Pre-Christian literature referred to several images which were ascribed a heav-

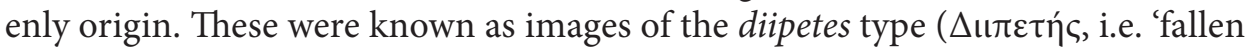
from Heaven' or 'sent by Zeus to the Earth') ${ }^{7}$. The best known of such images was probably the Trojan palladion ${ }^{8}$ (Lat. palladium). It is a wooden carving of the goddess Athena, believed to have the ability of preventing the conquest of the city which kept the object within its walls. The image was purported to wield immense power, and Athena became both the patroness and the protector of the

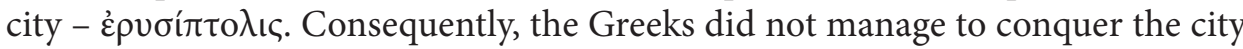
while its protector was still present there ${ }^{10}$. Apart from Troy, the towns of Argos and Lindos were in possession of a palladion as well, although these palladia were believed to have been of human making - unlike the Trojan one ${ }^{11}$. The image of Artemis from Ephesus, carved in wood, is to be counted among the images of the diipetes type ${ }^{12}$. It is even mentioned in the New Testament: The city of Ephesus is the guardian of the temple of the great Artemis and of her image, which fell from heaven (Act 19, 35).

The Egyptian metropolis of Alexandria owned an image of the ancient Egyptian god Serapis, created during the Ptolemaic reign in order to ensure a greater political and religious unity ${ }^{13}$. The god used to be depicted as man with a moustache,

\footnotetext{
${ }^{7}$ H.G. Liddell, R. Scott, A Greek English Lexicon, Oxford 1883, p. 370.

${ }^{8}$ Ernst von Doвschüтz (Christusbilder..., p. 2) claims that the term $\pi \alpha \lambda \lambda a ́ \delta ı$ ev emerged from a Semitic source, specifically originating from Phoenician palat 'to save, protect'. However, a more probable explanation is offered by Hjalmar Frisk, even though he states that the word's etymology is actually unknown. Since the term spread throughout various languages and cultures, uncovering its exact past is not possible. It may be derived from $\pi \alpha \lambda \lambda \alpha \kappa \eta$, which probably comes from Latin paelex, a concubine. Other meanings can be of a Semitic or Old Iranian origin. H. FRISK, Griechisches Etymologisches Wörterbuch, vol. II, Heidelberg 1970, p. 468-469.

${ }^{9}$ Cf. F. Bennet, A Study of the Word Eóavov, AJA 21, 1917, p. 8. Greek geographer, historian and philosopher Strabo (64 or 63 BC - 19-24 AD) mentions several types of these sculptures. StrABO, Geographica, IV, 1, 4; IV, 1, 5; VI, 1, 14, rec. A. Meineke, Lipsiae 1877; see also J. Papadopoulos, Xoana e sphyrelata. Testimonianza delle fonti scritte, Roma 1980, p. 15-65; M. Hurbanič, História a mýtus. Avarský útok na Konštantínopol roku 626 v legendách, Prešov 2010, p. 73; IDEM, Konstantinopol 626. Poslední bitva antiky, Praha 2016, p. 417.

${ }^{10}$ E. von Doвschüтz, Christusbilder..., p. 3.

${ }^{11}$ The Trojan palladion was kept in the main Athenian temple in the Acropolis, R. HošEK, Náboženství antického Řecka, Praha 2004, p. 50.

${ }^{12}$ Pausanias, Graeciae descriptio, I, 23, vol. I, Lipsiae 1829 (cetera: Pausanias), p. 9. Pausanias writes that Iphigenia, daughter of Agamemnon, brought the image to Athens and later to Argos, PAusanias, I, 33, p. 1. Euripides, Iphigenia in Tauris, trans. R. PotTer, London 1814, p. 1431-1464. The festivals of goddess Artemis were held every five years; on this occasion, five- to ten-year old girls wore saffrondyed garments, representing she-bears through their dance, see R. HošEK, Náboženství..., p. 52.

${ }^{13}$ D. Frankfurter, Religion in Roman Egypt. Assimilation and Resistance, Princeton-Chichester 1998, p. 169; H. Belting, In Search of Christ's Body. Image or Imprint?, [in:] The Holy Face and the
} 
resembling Zeus. Apart from Alexandria, his cult was widespread not only in the cities of Memphis, Sabrata, Leptis Magna, Rome or Ephesus, but also in the Danubian provinces ${ }^{14}$.

These palladia provided the inhabitants of the respective cities with significant and unquestionable authority. The images were publicly worshipped during various processions. In other words, the diipetes - 'fallen from heaven' - were a sort of pagan predecessor of Christian images not made by human hands. The cult of images (and not only it) was subject to a smooth and continuous transformation from the adoration of pagan objects and idols to the worship of Christian relics and artefacts.

As regards the appearance of the acheiropoietai, the only fact that we may point out in the light of the sources (since the mid- $6^{\text {th }}$ century onwards) is that they were created on pieces of cloth. Cloth, more specifically linen, was frequently used as a base for all kinds of images in both the West and the East throughout many centuries ${ }^{15}$.

\section{Old Testament prohibition of the worship of images}

The Christian tradition has preserved the premise that the first cult image - eikon

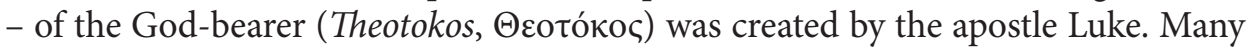
other images apart from the image of the Mother with the little Christ were ascribed to him; he was said to have created them with the inspiration of the Holy Spirit ${ }^{16}$.

The first account of Luke's image of the Theotokos comes from the $6^{\text {th }}$ century Ecclesiastical History by Theodore Anagnostes (also known as Theodorus Lector) ${ }^{17}$. It refers to a $5^{\text {th }}$-century event: Eudokia, wife of emperor Theodosius II (408-450), sent the image of the Theotokos from Jerusalem to Arcadius's daughter Pulcheria $^{18}$. A similar account is to be found in the $8^{\text {th }}$-century work by Andrew of Crete - De sanctarum imaginum veneratione. However, in contrast to the former source, this is no interpolation into the original text ${ }^{19}$. Theodore Anagnostes does not

Paradox of Representation. Papers from a Colloquium Held at the Bibliotheca Hertziana, Rome and the Villa Spelman, Florence, 1996, ed. H.L. Kessler, G. Wolf, Bologna 1998, p. 7.

${ }^{14}$ I. Shaw, Dějiny starověkého Egypta, trans. D. Feltová, Brno 2003, p. 456.

${ }^{15}$ Cf. E. Kitzinger, On Some Icons of the Seventh Century, [in:] Late Classical and Medieval Studies in Honor of Albert Mathias Friend, Jr., ed. K. Weitzmann, Princeton 1955, p. 141; J. Trilling, The Image..., p. 112.

${ }^{16}$ E. von Dobschütz, Christusbilder..., p. 269, 271; H. Belting, Bild und..., p. 65-66.

${ }^{17}$ Theodoros Anagnostes, Kirchengeschichte, 353, 9-10, ed. G.C. Hansen, Berlin 1971 [= GCS, 54] (cetera: Theodoros Anagnostes), p. 100. See also A.M. Lidov, Miracle-Working Icons of the Mother of God, [in:] Mother of God. Representations of the Virgin in Byzantine Art, ed. M. VAssiLAKI, Milan-London 2000, p. 48-49.

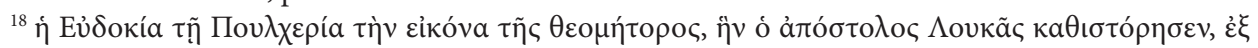

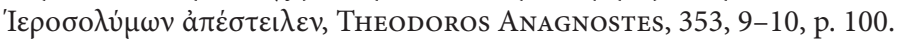

${ }^{19}$ Andreas Cretensis, De sanctarum imaginum veneratione, [in:] PG, vol. XCVII, col. 1304. 
describe the Theotokos more specifically, but Nikephoros Kallistos Xanthopoulos, a $14^{\text {th }}$-century patriarch of Constantinople, identified the God-bearer with

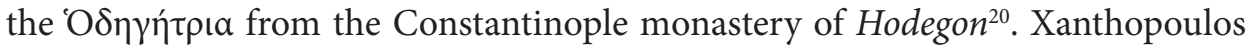
also substituted Jerusalem for the Syrian Antioch in the original legend of Anagnostes ${ }^{21}$. However, it is actually improbable that the apostle Luke could have created the $\mathrm{O} \delta \eta \eta \eta$ i $\rho\llcorner\alpha$ Theotokos. There were clear and strict rules regarding the creation of images in the Old Testament-based Christian religion, as the Old Testament God forbids idolatry and the manufacturing of idols, or anything aimed at winning their favour. Thus, it is prohibited to create images in the form of anything in heaven above or on the earth beneath or in the waters below (Ex 20,4-5).

Luke was converted by the apostle Paul, whose attitude to images was - again, in accordance with the Old Testament - manifestly negative: he placed it on the same level as idolatry. They exchanged the glory of the immortal God for images made to look like a mortal human being and birds and animals and reptiles (Rom 1, 23).

According to Paul's Epistle to the Romans - one of the books of the New Testament - people are used to preferring ephemeral and mundane things, thus suppressing God. Paul sharply rebukes such an attitude, as stated in the Acts of the Apostles. In Ephesus, he lectures the gathered masses that gods created by human

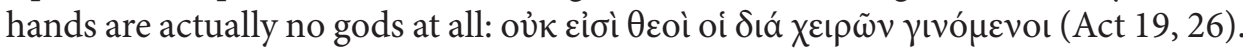

Returning to the image of the Theotokos, it is nevertheless correct to state - in a figurative sense - that it was Luke who created the first image of the Godbearer. He did indeed 'author' the image, although not in the sense of a real, tangible object. Rather, the image in question represents spiritual legacy, as he was the one who wrote about the Theotokos the most extensively out of all the evangelists.

In the first centuries after Christ, the original Christian communities accepted the so-called prohibition of depiction, widely known from several Old Testament books, namely the Second Book of Moses - Exodus, the Third Book of Moses - Leviticus, the Fifth Book of Moses - Deuteronomy, and the Book of Isaiah. According to the Book of Exodus, God forbids creating any idols as well as any attempts to win their favour by idolatry. People cannot bow to them or serve them (Ex 20, 4-5). The Third Book of Moses prohibits making idols, creating their carved images or monuments, or painted stones for people to bow down to them (Lv 26, 1). According to the Book of Deuteronomy, people should not manufacture graven images (for themselves):

\footnotetext{
${ }^{20}$ The source of Nikephoros Kallistos Xanthopoulos quotes the older $6^{\text {th }}$ century text by Theodore Anagostes. For more information see B.V. Pentcheva, Icons and Power. The Mother of God in Byzantium, University Park 2006, p. 120-121; M. HuRBAnIČ, Konštantínopol, tradícia avarského útoku z roku 626 a posvätné relikvie, SlSl 44, 2009, p. 113.

${ }^{21}$ Nicephorus Callistus Xanthopoulos, Historia ecclesiastica, XV, 14, [in:] PG, vol. CXLVII, col. 44 .
} 
in the form of any figure, the likeness of male or female, the likeness of any animal that is on the earth, the likeness of any winged bird that flies in the sky, the likeness of anything that creeps on the ground, the likeness of any fish that is in the water below the earth (Dt 4, 16-18).

Chapter 40 of the Book of Isaiah asks who God could be compared to (Is 40, 18). An image or any other comparison to God is identified as an idol as defined by the Old Testament and thus considered simply unacceptable ${ }^{22}$.

However, even in the Old Testament there are certain passages which could be interpreted as only outlawing the images of God (Ex 20, 23; Dt 27, 15). The Mediterranean area was traditionally known to favour images. Such an attitude towards images had already originated in pre-Christian times and managed to persist in the later periods, albeit only partially and locally. Despite the actual rejection of the cult of images by the first Christians, based on a clear interpretation of the biblical prohibition, we do not agree with Ernst Kitzinger's opinion that such a prohibition did not permit the application of any figurative motifs, which could be a part of a temple decoration, for instance ${ }^{23}$. Even in this case, there are some exceptions to be found; the best known one is the example from the Mesopotamian Dura-Europos.

This small fortified town on the bank of the Euphrates was known as a home to a Jewish diaspora community, with its own synagogue. Archaeological research has brought forth a surprising revelation: the interior of the synagogue was decorated with numerous $3^{\text {rd }}$-century mural paintings in the manner of an illustrated Bible ${ }^{24}$. Whole biblical cycles are to be found in the synagogue: the stories of Moses, Elias, Daniel and others. In fact, the synagogue makes the impression that its decorations are the predecessors of Byzantine mural painting ${ }^{25}$. Even if such a statement cannot be easily verified, it is quite obvious that the period

${ }^{22}$ Cf. A. Avenarius, Byzantský ikonoklazmus, 726-843. Storočie zápasu o ikonu, Bratislava 1998, p. 34; L. Brubaker, J.F. Haldon, Byzantium in the Iconoclast Era c. 680-850. A History, Cambridge 2011 , p. 40. John of Damascus (675/676 - 749 or 753) thought of idolatry in clearly negative terms, although he was the first one to distinguish clearly between an idol and an image. Referring to the. apostle Paul (Gal 4, 8-9), he claims that the period of idolatry ended when people accepted God (2Cor 5,17$)$. Thus, John of Damascus makes a sharp distinction between an Old Testament idol and a New Testament image; JoAnnes Damascenus, Contra imaginum calumniatores orationes tres, I, 1, ed. B. Kotter, Berlin 1975 [= PTS, 17]. See also A. Avenarius, Učenie Jána z Damašku o ikone: K problému stredovekého symbolizmu, HČSAV 46, 1998, p. 82. During the so-called iconoclasm period, the adherents of the prohibition of idolatry attempted to bring back these original Christian customs and traditions. The iconoclastic Synod of Constantinople enabled this de iure in 754 .

${ }^{23}$ E. KitZinger, The Cult..., p. 89.

${ }^{24}$ R. Hachlili, Ancient Jewish Art and Archeology in the Diaspora, Leiden 1998, p. 96-197;

G. Stemberger, Klasické židovství. Kultura a historie rabínské doby, Praha 2011, p. 193-194.

${ }^{25}$ E. SENDler, Ikona. Obraz neviditelného, Olomouc 2011, p. 14. 
in question witnessed an interesting set of experiments with figurative art among the Hellenised Jewish communities of the Middle East. However, it seems that it has not found any significant continuation in the next centuries.

The first Christian communities were not quite homogenous; while the prohibition of depiction was general, it was not actually observed everywhere, as the example of the Roman catacombs shows. Temple decorations of that time often included stylized plants (olive branches, apples) or geometrical ornaments (monograms) as well as symbols such as the cross, lamb, pelican, peacock or fish ${ }^{26}$. On the other hand, statues posed a problem for the Christians in the beginning; they never obtained such a status in the East as they enjoyed among the believers in the West. The reason was their temporariness, as they tended to rot, mould and decay with time. They would often be damaged by insects, infested by mice and soiled by birds $^{27}$. Due to the insufficiency of archaeological findings and literary sources, it is impossible to take a definite stance on this issue. Why should not the Christians of the first centuries actually have accepted visual depictions, statues or any other material symbols which would have led them in their chosen spiritual way? One of the possible answers might be the one offered by Irenaeus of Lyon (died circa 202), one of the most prominent theologians of the time, as well as bishop of Gallic Lugdunum (nowadays Lyon). In his work Contra haereses libri quinque, he displays an attitude of clear antagonism against images of Christ, considering them a relic from the pagan period. Book 1 mentions the Gnostic heresy of the so-called Carpocratians (Lat. Carpocrates), who:

\begin{abstract}
have images, some painted, some of other materials. They claim that the depiction of Christ was created by Pilate at the times when [Christ] lived amongst the people. They decorate these images and put them on display together with secular philosophers such as Pytaghoras, Plato, Aristotle or others. They worship these images also in other ways, similar to those of the pagans. ${ }^{28}$
\end{abstract}

Irenaeus condemns such behaviour and regards it as idolatry; he refuses to place images of Christ at the same level as depictions of philosophers. This negative attitude is aimed at distinguishing his beliefs strictly from paganism.

The Christian Church fought against the originally pagan custom of idolatry for a long time. On the one hand, there was of course the Old Testament prohibition of depicting; on the other hand, there were some acceptable exceptions when the point was not to depict the Divine entity as such, but rather to focus on the educational or pedagogical function of the image - a 'poor man's Bible' of sorts. Tertullian (circa 155 - circa 222) - a writer, lawyer and one of the most

\footnotetext{
${ }^{26}$ For example A. Avenarius, Byzantský..., p. 23.

${ }^{27}$ T.F.X. Noble, Images, Iconoclasm, and the Carolingians, Philadelphia 2009, p. 11.

${ }^{28}$ Irenaeus, Contra haereses libri quinque, I, 25, 6, [in:] PG, vol. VII, col. 685.
} 
distinguished Church Fathers - was at the same time one of the most ardent opponents of images. In his work De idolatria, he wrote that The biggest crime of the mankind, the worst wrongdoing there is, is idolatry ${ }^{29}$. He calls those participating in the idolatry murderers and condemns serving the false gods alongside adultery and fornication ${ }^{30}$. On the other hand, personalities such as for instance Hypatius, bishop of Ephesus, defended the above-mentioned function of images, namely their educational and didactic impact (specifically on illiterate people). Accordingly, Hypatius writes: This is a way how to teach those who are otherwise impossible to be taught $t^{31}$. Thus, the above quotations from the two prominent thinkers are an excellent illustration of both views and the insurmountable differences between them ${ }^{32}$.

Let us mention one more anecdote, probably dating back to the $4^{\text {th }}$ century:

Father Sopatros has been asked: Give me advice, father, and I shall follow it. Father Sopatros replied: Do not allow a woman to enter your cell and do not read apocryphal literature. Do not start debates on the image. Although this is not heresy, there is too much ignorance and fancies when disputing this issue between two parties. It is impossible to comprehend the truth. ${ }^{33}$

Images were symbols of those who had lost their physical body at the moment of their death; this implies a significant degree of reverence, aside from the didactic aspect $^{34}$. Before the times of the acheiropoietai, images of rulers (emperors, members of the imperial family etc.) were worshipped in view of their ability to serve as a substitute for the actual human beings. The veneration of imperial portraits was later transformed into reverence for images not made by human hands. Therefore, we shall briefly outline why and how the above-mentioned imperial images acquired their highly specific importance.

\footnotetext{
${ }^{29}$ Tertullian's exact words in his treatise are as follows: Principale crimen generis humani summus saeculi reatus, tota causa iudicii idolatria, Tertullianus, De idolatria, I, 1, ed. J.H. Waszink, J.C.M. van Winden, Leiden 1987 [= VC.S, 1] (cetera: Tertullianus).

${ }^{30}$ Tertullianus, I, 1.

${ }^{31}$ See P.J. Alexander, Hypatius of Ephesus: A Note on Image Worship in the Sixth Century, HTR 45, 1952, p. 180; S. Gero, Hypatius of Ephesus on Cult of Images, [in:] Christianity, Judaism and Other Graeco Roman Cults, ed. J. Neusner, M. Smith, Leiden 1975 [= SJLA, 12], p. 208-216; I.M. BugAR, Zacchaeus and Veneration of Images: Image of the Emperor - Image of a Saint, [in:] SP, vol. XXXIV, p. 11-22.

${ }^{32}$ For more on the subject, cf. M.P. KRUk, Sztuka $w$ cesarstwie rzymskim w IV wieku, [in:] Świat rzymski w IV wieku, ed. P. FiLıPCZAK, R. KosıńsKi, Kraków 2015, p. 460-462.

${ }^{33}$ Apophthegmata patrum, [in:] PG, vol. LXV, col. 413; cf. Ward's English translation: The Sayings of the Desert Fathers, trans. B. WARD, Kalamazoo 1984, p. 225.

${ }^{34}$ H. Belting, Bild und..., p. 54.
} 


\section{Imago imperialis}

Although the Christian cult of images might have only existed legally to a limited extent, its examples are to be found as early as the $4^{\text {th }}$ century onwards $s^{35}$. On the other hand, images of rulers are of a much earlier date. These cult pictures - or imperial portraits - did not depict Christ, the Theotokos, angels or saints; rather, they were images of the rulers themselves (imagines imperiales) ${ }^{36}$. There are various Latin and Greek expressions preserved on imperial images, such as sacra laurata,

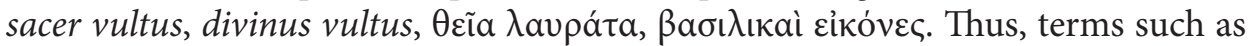
saint or divine were used in reference to emperors on their very portraits, too: after all, this was the way in which emperors styled themselves in public ${ }^{37}$.

It should be emphasised, however, that there is a continuity between imperial portraits and cult pagan depictions of imperial authority ${ }^{38}$. The cult of the emperor, manifested by faithful depictions, can be traced back to the Principate period (circa $27 \mathrm{BC}-284 \mathrm{AD})^{39}$. The sources attest that the imperial portrait practice can already be encountered as early as during the Julio-Claudian dynasty ${ }^{40}$. Imperial effigies symbolised power and a sovereign position within the society; during military coups, imperial images were among the first things to be destroyed at the imperial court.

Syrian bishop Severian of Gabala, who lived at the turn of the $4^{\text {th }}$ and $5^{\text {th }}$ century, wrote in his work De mundi creatione:

Just consider, how many officials [ä $\rho \chi 0 v \tau \varepsilon \varsigma^{41}$ ] there are in this world. Since an emperor cannot be present to all persons, it is necessary to set up the statue of the emperor in law courts,

${ }^{35}$ Ibidem, p. 86, 122; L. Brubaker, The Sacred Image, [in:] The Sacred Image. East and West, ed. R. Ousterhout, L. Brubaker, Urbana 1995 [= IBS, 4], p. 3.

${ }^{36}$ Some scholars simplify the division of images into three groups, placing sacred images of emperors somewhere in between icons and idols; A. Eastmond, Between Icon and Idol: The Uncertainty of Imperial Images, [in:] Icon and Word. The Power of Images in Byzantium, ed. A. EAstmond, L. James, Aldershot 2003, p. 73-86. See also H. Belting, Bild und..., p. 118-119; K.W. HarL, Sacrifice and Pagan Belief in Fifth- and Sixth-Century Byzantium, PP 128, 1990, p. 9; R.M. JENSEN, Face to Face. Portraits of the Divine in Early Christianity, Minneapolis 2005, p. 234.

${ }^{37}$ Seе А. Гравар, Император в византийском искусстве, Москва 2000, p. 25.

${ }^{38}$ Cf. H. Kruse, Studien zur offiziellen Geltung des Kaiserbildes im römischen Reiche, Paderborn 1934 [= SGKA, 19.3], p. 116; А. ГРАБАР, Император..., p. 328. See J. DÉER, Der Globus des spätrömischen und des byzantinischen Kaisers. Symbol oder Insigne?, BZ 54, 1961, p. 53-85; G.B. LADNER, Images and Ideas in the Middle Ages. Selected Studies in History and Art, Roma 1983, p. 51.

${ }^{39}$ Actually, there are some images of emperors even from an earlier period, though not to such an extent; I. GRADEL, Emperor Worship and Roman Religion, Oxford 2002 [= OCM], p. 398.

${ }^{40}$ Cassius Dio, Historia Romana, LXIII, 25, vol. V, ed. L.A. Dindorf, Lipsiae 1865 [= BSGR]; TACITUs, $Z$ dějin císařského Říma. Dějiny, I, 41; III, 12; III, 13; III, 31, trans. A. Minařík, A. Hartmann, V. Bahník, Praha 1976; Plutarchos, Životopisy slávnych Grékov a Rimanov, 26, vol. II, trans. D. ŠKoviera, P. KuklicA, Bratislava 2008.

${ }^{41}$ Understood as the ruler's deputy, authorised representative, member of the high society/elite. 
market places, public assemblies ['́v $\sigma \nu \lambda \lambda$ ó $\gamma o \iota c]$, and theatres. In every place, in fact, where an official acts, the imperial effigy must be present, so that the emperor may thus confirm whatever takes place. For the emperor is only a human being, and he cannot be present everywhere. ${ }^{42}$

Severian aptly captures both the meaning and the necessity of existence of cult images during the Roman period. The emperor had to be an omnipresent figure. He presided all the important state and church ceremonies; if he could not attend some of those in person, he was represented by his depiction, which served as his complete substitution. Imperial images held a place of honour in any public space ${ }^{43}$. Sometimes, it was the effigy of the emperor that presided over games in the circus ${ }^{44}$. Among other things, the image of the emperor played an irreplaceable role during court proceedings ${ }^{45}$. A similar phenomenon can be seen in the $6^{\text {th }}$-century Rossano Gospels or Codex purpureus Rossanensis, one of the oldest and most unique illuminated manuscripts in existence. Although only less than half of the work has been preserved, there are two extant scenes containing imperial portraits. Christ, standing in front of Pilate, is surrounded by members of the latter's camarilla, holding imperial images ${ }^{46}$. The portrait of the emperor was not only an official symbol but also an object of cult reverence ${ }^{47}$.

A similar manifestation of respect - even fear - related to the depiction of an emperor can be observed in other cultures as well. Thus, a statue of emperor Trajan (98-117) was allegedly kept in the $6^{\text {th }}$-century Sassanid Empire. It was reported to arouse such respect, or even awe, that soldiers were afraid to sit on their horses whenever they approached the statue. In the end, it was pulled down by Khosrow I at the times of the Byzantine-Sassanid wars, as it was believed to symbolize Roman superiority over the Sassanid realm ${ }^{48}$.

There are even accounts claiming that images of emperors marked the borders of the empire. They would be placed on pillars or artificially elevated places made of brass and marble, with the aim of indicating the Roman limes. However, this information is not supported by any archaeological findings, as no similar artefacts have been preserved on the eastern Roman border ${ }^{49}$. On the other

\footnotetext{
${ }^{42}$ Severianus Gabalensis, De mundi creatione, or. VI, 5, [in:] PG, vol. LVI, col. 490.

${ }^{43}$ H. Kruse, Studien..., p. 12.

${ }^{44}$ А. ГРАБАР, Император..., p. 26.

${ }^{45}$ H. Kruse, Studien..., p. 80.

${ }^{46}$ W. Sanday, The Text of the Codex Rossanensis, [in:] Studia Biblica. Essays in Biblical Archeology and Criticism and Kindred Subjects, ed. S.R. Driver, W. Sanday, J. Wordsworth, Oxford 1885, p. 103-112. See also C.R. Gregory, Textkritik des Neuen Testamentes, Leipzig 1900, p. 92.

${ }^{47}$ H. Belting, Bild und..., p. 118.

${ }^{48}$ With reference to John of Ephesus - see W.E. KAEGI, Byzantium and the Early Islamic Conquest, Cambridge 1992, p. 166.

${ }^{49}$ Ibidem.
} 
hand, John Malalas writes that at the times of Diocletian (284-305), statues of the emperor and caesar were to be found on the Syrian border ${ }^{50}$.

Besides, John Malalas's chronicle from the mid- $6^{\text {th }}$ century states, for example, that Constantine the Great carried his own image during the festive procession on the day of the foundation of the city of Constantinople ( $11^{\text {th }}$ May). In this way, he intended to demonstrate that this day was his and his exclusively ${ }^{51}$.

In the $5^{\text {th }}, 6^{\text {th }}$, but also $14^{\text {th }}$ century, we encounter the phenomenon of depicting the emperor or members of the imperial family on the upper part of the garment of important court officials. Images of the royals' faces and upper body were stitched on or woven into clothes. This was the way in which emperors would mark their favourite members of the court; thus, such a garment was supposed to serve as a distinction ${ }^{52}$. Book 17 of Malalas's chronicle records an account concerning a certain successor to the throne of Lazika - an area of constant strategic interest for the Sassanids. Basileus Tzathios I refused Sassanid rule over his kingdom and instead chose the Byzantine Empire, ruled at the time by Justin I (518-527), as his ally. Apart from being married to a granddaughter of an influential Constantinople patrician, he was crowned with an imperial crown, wearing a tunic of pure silk ${ }^{53}$. However, there was a golden - not purple - hem on the tunic, containing a purple portrait of the emperor in the middle ${ }^{54}$. Images of emperors were also to be found on objects intended as gifts heading abroad. These presents were meant to mark a victory or confirm an agreement, cooperation, or the emperor's protection. Even rings, seals, diadems, ceremonial garments or indeed anything else bearing the emperor's likeness could serve as such a gift ${ }^{55}$.

In his De administrando imperio, Constantine Porphyrogenitus (905-959) mentions the Western Roman emperor Anthemius (467-472), whose portrait was received at the court of Eastern Roman emperor Leo I (457-474). The Eastern emperor had helped Anthemius become emperor in the West. Naturally, he was pursuing his own goals, trying to avoid the succession of Olybrius, who was close to Genseric, King of the Vandals. To further support this policy, in the year of the coronation, he had an image of Anthemius (decorated with laurels) received in Constantinople with great splendour. The reception and acceptance of this picture meant the recognition of Anthemius himself as co-emperor ${ }^{56}$ : his image was paid the same homage that he would have received in person.

\footnotetext{
${ }_{50}^{50}$ Joannes Malalas, Chronographia, XII, 308, ed. L. DindorfiI, Bonnae 1831 [= CSHB] (cetera: Joannes Malalas).

${ }^{51}$ Joannes Malalas, XIII, 322.

52 А. ГРАБАР, Император..., p. 26.

${ }^{53}$ Joannes Malalas, XVII, 412-413.

${ }^{54}$ Joannes Malalas, XVII, 413.

${ }^{55}$ А. ГРАБАР, Император..., p. 27-28.

${ }^{56}$ Constantine Porphyrogenitus, De ceremoniis aulae Byzantinae, I, 87, vol. I, ed. J.J. Reiske, Bonn 1929; H. Kruse, Studien..., p. 28-30; H. Belting, Bild und..., p. 119.
} 
As early as at his acclamation, a new emperor was to be paid tribute by means of the so-called proskynesis, either in person at the court in Constantinople or via his effigy (in the more remote regions of the empire) ${ }^{57}$. This act connected with reverence for the imperial image was later transferred onto the acheiropoietai.

The converse of the above process was valid as well: the destruction of imperial portraits expressed the deposition or general non-acceptance of the rulers themselves. In 324, Constantine the Great was outraged by the destruction of his busts and statues by Licinius in the border zone near Emona (nowadays Ljubljana, Slovenia). As it turned out, Constantine used this as a pretext for declaring war on Licinius ${ }^{58}$.

Some of the Christian Church Fathers were willing to back the cult of the emperor (consisting in the veneration of imperial images) in exchange for the official acknowledgment of the Christian church, including support in the form of state endowment ${ }^{59}$. Christian thinking came closer to Greek philosophy and culture, thus also becoming more distanced from its original form, where the creation of images had been considered an unacceptable sin.

Thus, imperial images - although only mentioned here briefly - contributed greatly to the change in the perception of images in general. The manifestation of immense tribute which had been paid to the person of the emperor exclusively was transformed onto his sacred likeness ${ }^{60}$. Suddenly, the emperor and his effigy appeared to be the same. The image served as the emperor's deputy in places where the sovereign could not be present in person ${ }^{61}$. The imagines imperiales wielded the same authority as their model; real imperial personality and its portraits were regarded at the same level. Thus, homage and all other honours were paid not only to the emperor but to his image representation as well - since it served as his full-bodied substitution ${ }^{62}$.

\footnotetext{
${ }^{57}$ H. Kruse, Studien..., p. 37; H. Belting, Bild und..., p. 119; A. Cameron, The Language of Images: The Rise of Icons and Christian Representation, SCH 28, 1992, p. 9.

${ }^{58}$ Origo Constantini imperatoris sive Anonymi Valesiani pars prior, 5, [in:] Chronica Minora, saec. IV, $V, V I, V I I$, ed. T. Mommsen, Berolini 1892, p. 15-16.

${ }^{59}$ Basilius Magnus, Liber de spiritu sancto, 18, 45, [in:] PG, vol. XXXII, col. 149; The Art of the Byzantine Empire 312-1453, ed. C. MANGo, Toronto-London 1986, p. 47.

${ }^{60} 6^{\text {th }}$ century Syrian chronicler John Malalas was the first to write about the reverence for sacred imperial images in the Byzantine Empire, specifically related to Constantine the Great. According to Malalas, Constantine introduced the practice when his image was carried in the festive procession on the occasion of the foundation of Constantinople, when the masses were to bow to this image; Joannes Malalas, XIII, cf. Scriptores originum Constantinopolitanarum, II, rec. T. Preger, Lipsiae 1907, p. 42-43; H. Belting, Bild und..., p. 117-129; A. Eastmond, Between Icon ..., p. 74. In Rome, imperial images from Constantinople were received until the $8^{\text {th }}$ century as a substitution for the absent Byzantine emperors. In order to manifest the latter's sovereignty over the city, the images were to be carried in a procession to a chapel on the Palatine Hill (G. Wolf, Salus Populi Romani. Die Geschichte römischer Kultbilder im Mittelalter, Weinheim 1990, p. 7-8).

${ }^{61}$ E. Kitzinger, The Cult..., p. 122.

${ }^{62}$ H. Kruse, Studien..., p. 30; H. Belting, Bild und..., p. 119.
} 
Our example of the veneration of the imagines imperiales demonstrates the power of the cult of images. Understanding the worship of images of rulers is the first step in grasping the reverence for religious images, in particular the acheiropoietai from the second half of the $6^{\text {th }}$ century onwards. The veneration of Christian images not made by human hands was directly based on the experience with paying homage to imperial images: as in the case of the latter, the picture was supposed to replace the actual figure depicted in it. Acheiropoietai were created through direct contact with Christ - whom they also depicted. Kitzinger divides images not made by human hands into two groups: those that were not created by the hand of a mortal according to the tradition (as for instance the Image of Edessa, the Shroud of Turin or the Vera icona $)^{63}$ and those that were created mechanically - the mortal acting as a mediator in this case - but still possessed magical power and represented a sort of reflection or imprint of an image not made by human hands (the so-called Image of Camuliana as well as the two images which were created due to its effect, or the Keramion - the print of Christ's face on a roof tile, as recorded in the $10^{\text {th }}$-century Narratio de imagine Edessena $)^{64}$.

Judging by the sources, acheiropoietai started appearing within the vastness of the Byzantine world and the Christian Orient a priori starting in the second half of the $6^{\text {th }}$ century. They constitute some remnants of - or rather, especially considering the images of the diipetes type, the continuation of - the pre-Christian era. Images not made by human hands were venerated for their apotropaic effects, as they were believed to turn away harm or evil influences; thus, their possession supposedly guaranteed safety for a given location (e.g. preventing the conquest of a city). Their importance resided in their embodying the model they depicted. Emperors often carried these images when going to battle in order to ensure military luck, which their magical powers were thought to bring.

Why the $6^{\text {th }}$ century in particular, however? No simple or precise answer can in fact be given. The rise and spread of the acheiropoietai in the second half of the $6^{\text {th }}$ century, in particular during the reign of emperor Justinian (527-565), was influenced by various factors which can be divided into three main categories, as presented below ${ }^{65}$.

Firstly, there existed reasons of a political and military nature. Byzantium may have achieved the restoration of the borders of the former Eastern Roman Empire - but only at the cost of permanent war. The wars with the Vandals and Persia, the Slavic penetration of the Byzantine limes and the costly and exhausting campaign

\footnotetext{
${ }^{63}$ Cf. M. Gogola, Mandylion z Edessy. Rukou-nestvorený obraz a jeho miesto v byzantskom umení a duchovnej kultúre, Bratislava 2017, passim. Concerning the term Mandylion, see M.P. KRUK, Mandylion, [in:] EK, vol. XI, p. 1135-1137.

${ }^{64}$ E. Kitzinger, The Cult..., p. 113; see also M. Gogola, Narratio de imagine Edessena ako jeden zo základných prameňov v genéze legiend $k$ dejinám edesského obrazu, [in:] Byzantinoslovaca V. Zborník k životnému jubileu Tatiany Štefanovičovej, Bratislava 2014, p. 181-191.

${ }^{65}$ See J. Trilling, The Image..., p. 109-127.
} 
in Italy - all of this was happening at the same time as buying peace on the eastern border by paying exorbitant sums of money. Hence, wars and the resulting economic burden had significantly weakened the Empire. Secondly, the second half of the $6^{\text {th }}$ century was a period of natural disasters (appearance of a comet, catastrophic droughts, plague epidemics, etc.) as well as social turmoil (famine, the Nika Riot) in Justinian's empire ${ }^{66}$. Thus, the people were in need of turning to something they could possibly believe in. Finally, the Hellenic world was clearly in favour of the veneration of images, a phenomenon stemming from Antique times and considered an inseparable part of Hellenic culture. The people of the region had a markedly spiritual attitude to their beliefs in comparison with the more rational Occident. Therefore, it is no coincidence that acheiropoietai first emerged in Syria and Asia Minor, i.e. the areas known for their pre-Christian tradition of venerating diipetes images.

\section{Bibliography}

\section{Primary Sources}

Andreas Cretensis, De sanctarum imaginum veneratione, [in:] Patrologiae cursus completus, Series graeca, vol. XCVII, ed. J.-P. Migne, Paris 1865, col. 1301-1304.

Apophthegmata patrum, [in:] Patrologiae cursus completus, Series graeca, vol. LXV, ed. J.-P. Migne, Paris 1864, col. 71-442.

Basilius Magnus, Liber de spiritu sancto, [in:] Patrologiae cursus completus, Series graeca, vol. XXXII, ed. J.-P. Migne, Paris 1886, col. 67-218.

CAssius Dio, Historia Romana, vol. V, ed. L.A. Dindorf, Lipsiae 1865 [= Bibliotheca scriptorum Graecorum et Romanorum Teubneriana].

Constantine Porphyrogenitus, De ceremoniis aulae Byzantinae, vol. I, ed. J.J. Reiske, Bonn 1929. Euripides, Iphigenia in Tauris, trans. R. PотTer, London 1814.

Irenaeus, Contra haereses libri quinque, [in:] Patrologiae cursus completus, Series graeca, vol. VII, ed. J.-P. Migne, Paris 1857, col. 433-1224.

Joannes Damascenus, Contra imaginum calumniatores orationes tres, ed. B. Kotter, Berlin 1975 [= Patristische Texte und Studien, 17].

Joannes Malalas, Chronographia, ed. L. Dindorfil, Bonnae 1831 [= Corpus scriptorum historiae Byzantinae].

Nicephorus Callistus Xanthopoulos, Historia ecclesiastica, XV-XVIII, [in:] Patrologiae cursus completus, Series graeca, vol. CXLVII, ed. J.-P. Migne, Paris 1865, col. 9-448.

Origo Constantini imperatoris sive Anonymi Valesiani pars prior, [in:] Chronica Minora, saec. IV, V, VI, VII, ed. T. Mommsen, Berolini 1892.

Pausanias, Graeciae descriptio, vol. I, Lipsiae 1829.

${ }^{66}$ J.F. Haldon, Byzantium in the Seventh Century. The Transformation of a Culture, Cambridge 1990, p. 355-370; H. Belting, Bild und..., p. 69. 
Plutarchos, Životopisy slávnych Grékov a Rimanov, vol. II, trans. D. ŠKoviera, P. Kuklica, Bratislava 2008.

The Sayings of the Desert Fathers, trans. B. WARD, Kalamazoo 1984.

Scriptores originum Constantinopolitanarum, rec. T. Preger, Lipsiae 1907.

Severianus Gabalensis, De mundi creatione, [in:] Patrologiae cursus completus, Series graeca, vol. LVI, ed. J.-P. Migne, Paris 1859, col. 429-500.

Strabo, Geographica, rec. A. MeIneKe, Lipsiae 1877.

Tacitus, $Z$ dějin císařského Říma. Dějiny, trans. A. MinaŘík, A. Hartmann, V. Bahník, Praha 1976.

Tertullianus, De idolatria, ed. J.H. Waszink, J.C.M. van Winden, Leiden 1987 [= Supplements to Vigiliae Christianae, 1].

Theodoros Anagnostes, Kirchengeschichte, ed. G.C. Hansen, Berlin 1971 [= Die griechischen christlichen Schriftsteller der ersten drei Jahrhunderte, 54].

\section{Secondary Literature}

Alexander P.J., Hypatius of Ephesus: A Note on Image Worship in the Sixth Century, "The Harvard Theological Review" 45, 1952, p. 177-184.

The Art of the Byzantine Empire 312-1453, ed. C. Mango, Toronto-London 1986.

Avenarius A., Byzantský ikonoklazmus, 726-843. Storočie zápasu o ikonu, Bratislava 1998.

Avenarius A., Učenie Jána z Damašku o ikone: K problému stredovekého symbolizmu, "Historický časopis" 46, 1998, p. 79-93.

Belting H., Bild und Kult. Eine Geschichte des Bildes vor dem Zeitalter der Kunst, München 1990.

Belting H., In Search of Christ's Body. Image or Imprint?, [in:] The Holy Face and the Paradox of Representation. Papers from a Colloquium Held at the Bibliotheca Hertziana, Rome and the Villa Spelman, Florence, 1996, ed. H.L. Kessler, G. Wolf, Bologna 1998, p. 1-11.

BenNet F., A Study of the Word Eóxvov, "American Journal of Archaeology" 21, 1917, p. 8-21.

Brubaker L., Conclusion: Image, Audience and Place: Interaction and Reproduction, [in:] The Sacred Image. East and West, ed. R. Ousterhout, L. Brubaker, Urbana 1995 [= Illinois Byzantine Studies, 4], p. 204-220.

Brubaker L., The Sacred Image, [in:] The Sacred Image. East and West, ed. R. Ousterhout, L. Brubaker, Urbana 1995 [= Illinois Byzantine Studies, 4], p. 1-24.

Brubaker L., Haldon J.F., Byzantium in the Iconoclast Era c. 680-850. A History, Cambridge 2011.

Bugar I.M., Zacchaeus and Veneration of Images: Image of the Emperor - Image of a Saint, [in:] Studia Patristica, vol. XXXIV, ed. M. Wiles, E. Yarnold, P. Parvis, Louvain 2001, p. 11-22.

CAmeron A., The Language of Images: The Rise of Icons and Christian Representation, "Studies in Church History" 28, 1992, p. 1-42.

Cormack R., Miraculous Icons in Byzantium and Their Powers, "Arte Cristiana" 76, 1988, p. 55-60.

DÉER J., Der Globus des spätrömischen und des byzantinischen Kaisers. Symbol oder Insigne?, "Byzantinische Zeitschrift" 54, 1961, p. 53-85.

Dовлснӥтz E. von, Christusbilder. Untersuchungen zur christlichen Legende, Leipzig 1899 [= Texte und Untersuchungen zur Geschichte der altchristlichen Literatur, 18].

Eastmond A., Between Icon and Idol: The Uncertainty of Imperial Images, [in:] Icon and Word. The Power of Images in Byzantium, ed. A. EAstmond, L. JAMES, Aldershot 2003, p. 73-85. 
Frankfurter D., Religion in Roman Egypt. Assimilation and Resistance, Princeton-Chichester 1998.

Frisk H., Griechisches Etymologisches Wörterbuch, vol. II, Heidelberg 1970.

Gero S., Hypatius of Ephesus on Cult of Images, [in:] Christianity, Judaism and Other Graeco Roman Cults, ed. J. Neusner, M. Smith, Leiden 1975 [= Studies in Judaism in Late Antiquity, 12], p. 208-216.

Gogola M., Mandylion $z$ Edessy. Rukou-nestvorený obraz a jeho miesto v byzantskom umení a duchovnej kultúre, Bratislava 2017.

Gogola M., Narratio de imagine Edessena ako jeden zo základných prameňov v genéze legiend k dejinám edesského obrazu, [in:] Byzantinoslovaca V. Zborník k životnému jubileu Tatiany Štefanovičovej, Bratislava 2014, p. 181-191.

Grabar A., Imperator v vizantijskom iskusstve, Moskva 2000.

Gradel I., Emperor Worship and Roman Religion, Oxford 2002 [= Oxford Classical Monographs].

Greek Papyri in the British Museum. Catalogue with Texts, vol. III, ed. F.G. Kenyon, H.I. BeLl, Milano 1973.

Gregory C.R., Textkritik des Neuen Testamentes, Leipzig 1900.

Hachlili R., Ancient Jewish Art and Archeology in the Diaspora, Leiden 1998.

Haldon J.F., Byzantium in the Seventh Century. The Transformation of a Culture, Cambridge 1990.

HARL K.W., Sacrifice and Pagan Belief in Fifth-and Sixth-Century Byzantium, "Past and Present" 128, 1990, p. 7-27.

HošEK R., Náboženství antického Řecka, Praha 2004.

Hurbanič M., História a mýtus. Avarský útok na Konštantínopol roku 626 v legendách, Prešov 2010.

Hurbanič M., Konstantinopol 626. Poslední bitva antiky, Praha 2016.

Hurbanič M., Konštantínopol, tradícia avarského útoku z roku 626 a posvätné relikvie, "Slavica Slovaca" 44, 2009, p. 106-118.

Jensen R.M., Face to Face. Portraits of the Divine in Early Christianity, Minneapolis 2005.

KAEGI W.E., Byzantium and the Early Islamic Conquest, Cambridge 1992.

Kitzinger E., On Some Icons of the Seventh Century, [in:] Late Classical and Medieval Studies in Honor of Albert Mathias Friend, Jr., ed. K. Weitzmann, Princeton 1955, p. 132-150.

Kitzinger E., The Cult of Images in the Age before Iconoclasm, "Dumbarton Oaks Papers" 8, 1954, p. $83-150$.

Kruk M.P., Mandylion, [in:] Encyklopedia Katolicka, vol. XI, ed. S. WiLK et al., Lublin 2006, p. 1135-1137.

KRUK M.P., Sztuka w cesarstwie rzymskim w IV wieku, [in:] Świat rzymski w IV wieku, ed. P. FiLIPCZAK, R. KosińsKi, Kraków 2015, p. 437-485.

Kruse H., Studien zur offiziellen Geltung des Kaiserbildes im römischen Reiche, Paderborn 1934 [= Studien zur Geschichte und Kultur des Altertums, 19.3].

LAdNer G.B., Images and Ideas in the Middle Ages. Selected Studies in History and Art, Roma 1983.

Liddell H.G., Scott R., A Greek English Lexicon, Oxford 1883.

Lidov A.M., Miracle-Working Icons of the Mother of God, [in:] Mother of God. Representations of the Virgin in Byzantine Art, ed. M. Vassilaki, Milan-London 2000, p. 47-57.

Mitteis L., Wilcken U., Grundzüge und Chrestomathie der Papyruskunde, Hildesheim 1963.

Noble T.F.X., Images, Iconoclasm, and the Carolingians, Philadelphia 2009. 
Papadopoulos J., Xoana e sphyrelata. Testimonianza delle fonti scritte, Roma 1980.

Pentcheva B.V., Icons and Power. The Mother of God in Byzantium, University Park 2006.

Sanday W., The Text of the Codex Rossanensis, [in:] Studia Biblica. Essays in Biblical Archeology and Criticism and Kindred Subjects, ed. S.R. Driver, W. SAndaY, J. Wordsworth, Oxford 1885, p. 103-112.

Sendler E., Ikona. Obraz neviditelného, Olomouc 2011.

Shaw I., Dějiny starověkého Egypta, trans. D. Feltová, Brno 2003.

Stemberger G., Klasické židovství. Kultura a historie rabinské doby, Praha 2011.

Trilling J., The Image Not Made by Hands and the Byzantine Way of Seeing, [in:] The Holy Face and the Paradox of Representation. Papers from a Colloquium Held at the Bibliotheca Hertziana, Rome and the Villa Spelman, Florence, 1996, ed. H.L. Kessler, G. Wolf, Bologna 1998, p. 109-127.

Wolf G., Salus Populi Romani. Die Geschichte römischer Kultbilder im Mittelalter, Weinheim 1990.

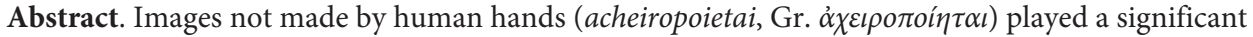
role in Byzantine spiritual culture and history. This paper discusses the emergence and rise of the acheiropoietai, which represented a most important and unusual element in the Byzantine Empire. THe author analyses the chronological ancestors of Christian images not made by human hands, i.e. the so-called diipetes (Gr. $\Delta u \pi \varepsilon \tau \eta \dot{\zeta}$ ), and proceeds to demonstrate the disagreements on the topic among some of the Christian Church Fathers. THe imagines imperiales, i.e. effigies of Roman emperors, constituted a significant factor in the process leading to the later veneration of images not made by human hands. The most famous of the latter is the image from Edessa, also known in historiography as Mandylion of Edessa.
\end{abstract}

Keywords: Byzantine spiritual culture, Byzantine history, images not made by human hands, acheiropoietai

Matej Gogola

Institute of Social Medicine and Medical Ethics

Faculty of Medicine

Comenius University in Bratislava

Sasinkova 2

81372 Bratislava, Slovakia

matej.gogola@gmail.com 